DOI: https://doi.org/10.18371/fp.3(35).2019.190166

УДК 658.5.011

\title{
АНАЛІЗ ДІЮЧОЇ СТРАТЕГІЇ РОЗВИТКУ ПІДПРИЄМСТВА З ВИКОРИСТАННЯМ ПРАКСЕОЛОГІЧНОГО ПІДХОДУ
}

\author{
кОЛМАКОВА Олена Миколаївна \\ кандидат економічних наук, дочент, \\ дочент кафедри економіки, \\ Харківський наџіональний університет будівнищтва та архітектури \\ ORCID ID: http://orcid.org/0000-0003-0908-5445 \\ e-mail:elenkolmakova78@gmail.com
}

\section{ОРЯБИНСЬКА Валентина Андріївна}

студентка,

Харківський національний університет будівництва та архітектури

ORCID ID: http://orcid.org/0000-0001-9114-0620

e-mail:valyun4ik96@gmail.com

Анотація: Досліджено існуючу «Програму розвитку КП «Харківводоканал» на 2015 2026 рр.» в аспекті стратегічного розвитку комунального підприємства та проведено оцінку ї̈ розділу "Підвищення енергоефективності, за рахунок реалізації заходів $з$ енергозбереження», використовуючи праксеологічний метод; запропоновані дочільні напрямки політики енергозбереження, розширення та проведення детального аналізу можливих шляхів енергозбереження. Виділено напрямки розвитку даного підприсмства: фінансова безпека, енергетична безпека підприємства.

Ключові слова: праксеологія, праксеологічний метод, стратегія, розвиток, оцінка, комунальне господарство

Постановка проблеми. В стратегії розвитку міста Харкова зазначено, що при обговореннях під час «круглих столів» (які були проведені з 15 червня до 25 липня 2016 року, в яких взяли участь 700 громадян міста, що
Аннотация: Исследована существующая «Программа развития КП «Харьковводоканал» на 2015-2026 г2.» в аспекте стратегчческого развития коммунального предприятия и оиенка его раздела «Повышение энергоэффективности за счет реализачии мероприятий по энергосбережению», используя праксеологический метод, предложенные иелесообразные направления политики энергосбережения, расширение и проведения детального анализа возможных путей энергосбережения. Выделень направления развития данного предприятия: финансовая безопасность, энергетическая безопасность предприятия.

Ключевые слова: праксеология, праксеологический метод, стратегия, развитие, оценка, коммунальное хазяйство.

представляли інтереси різних соціальних груп) були виявлені наступні проблеми: 1) стан житловокомунального господарства; 2) стан соціального захисту i зайнятості населення; 3) стан науки та освіти 
екології; 4) стан інженерної інфраструктури і транспорту [1, с. 81]. На першому місці стали саме проблеми житлово-комунального сектору. Головною проблемою $\epsilon$ зношення та моральна застарілість інженерних мереж водопостачання та водовідведення. Саме тому виникає потреба стратегічного планування розвитку комунальних підприємств та їх переоснащення 3 урахуванням новітніх технологій та вимог сучасності.

В сучасному світі основним пріоритетом енергетичної галузі $\epsilon$ відновлюваність джерела енергії та його екологічність. Використання альтернативних джерел енергії дозволяє посилити економічну та енергетичну безпеки держави. Помірно-континентальний клімат Україні обумовлює наявність опалюваного сезону, а відповідно потребу в енергії. Вартість кожного товару та послуги містить в собі вартість енергії. Відповідно енергетична політика держави безпосередньо впливають на соціально-економічний стан України. Що підтверджує актуальність теми дослідження.

Аналіз останніх досліджень i публікацій. Теоретичні й прикладні аспекти економічної стратегії розвитку підприємств висвітлені в роботах Р. Акоффа, I. Ансофа, І.Т.Балабанова, I.О. Бланка, М. Портера, А. Томпсона, О.М. Колмакової, В.В. Смачило [2] та ін. Визначення поняття «праксеологія» надане у роботах Л. Бурдьє, А.Еспінаса, Людвіга фон Мізеса та Т.Котарбінського.

Формуванні цілей статті. Дана стаття $є$ спробою об'єднати інформацію дослідників, лідерів думок, практиків та осіб, які приймають рішення, 3 власним досвідом, у цілісну систему застосування праксеологічного методу до стратегіï розвитку КП «Харківводоканал», щоб вплинути на успішну трансформацію стратегії комунального підприємства. Для цього виникає необхідність в об'єднанні ідей, методів, дій та праксеології. Головною ціллю даної статті $\epsilon$ виявлення та вивчення факторів підвищення ефективності дій щодо формування діючої стратегії на основі праксеологічного підходу.

Виклад основного матеріалу. Проаналізувавши вибір стратегій для комунальних підприємств, можна сказати, що є декілька методів стосовно формулювання стратегії та певні рамки, до яких вони вписуються.

Виникає необхідність дати загальне визначення поняттю «стратегія» - це основний значущий напрям певних дій комунального підприємства, реалізувавши які, призведе до заданої мети. Дане розуміння стратегії буде чітким при розгляді даного поняття на верхньому рівні управління, а саме - в органі місцевого самоврядування.

У 2017 році робота виконавчих органів Харківської міської ради, як і раніше, була спрямована на вирішення основних завдань соціально-економічного розвитку Харкова: підвищення конкурентоспроможності та інвестиційної привабливості міста, розвиток реального сектора економіки, забезпечення стабільного функціонування соціальної, інженернотранспортної та комунальної інфраструктури міста, поліпшення якості 
життя та належного рівня соціального захисту населення.

Багато в чому завдяки цій політиці і системно побудованої роботі виконавчих органів Харківської міської ради місто Харків є одним з провідних обласних центрів країни 3 великим економічним та людським потенціалом.

Головну роль стратегічного управління комунальним підприємстввом займають правила, що пояснюють функціонування комунального підприємства, але, порівнюючи зі стратегіями, не мають цілістності. Дані правила можна охарактеризувати як орієнтовані, обмежувальні, що створюють повну картину функціонування. Деякі 3 вищезазначених мають широкий сенс, але інші - у певній мірі вузький, що має відношення до окремої характеристики комунального підприємства на реалізацію заданих стратегій.

Більшість

правил

мають довготривалий характер. Так наприлад, $€$ н них ті, що в повній мірі реалізують конкретну стратегію, або існують задля реалізації первної мети. Вищезазначені правила можна охарактеризувати як предмет стратегічного управління, але тільки якщо стратегічне завдання комунального підприємства - реорганізація внутрішнього життя підприємства та його організаційної культури.

Якщо представити організаційну ієрархію териротріального управління, то для нижчого рівня верхній буде за мету, хоча для вищого рівня вона була лише засобом. Тобто взявши стратегію формування ринку комунальних послуг, що розроблена в цілому для міста, для конкретного комунального підприємства та його підлеглих буде цільовою настановою [4]. Щоб позбутися визначення загального поняття стратегіï, далі в цій статті буде розглядатися тільки стратегія комунального підприємства вцілому, застосовуючи праксеологічний підхід.

Вперше поняття "праксеологія" було застосоване Л. Бурдьє, а трохи пізніше - французьким соціологом А.Еспінасом, який окреслював праксеологію як окрему наукову дисципліну. [6] Завданням праксеології $\epsilon$ аналітичний опис техніки, елементів i форм раціональної діяльності, створення «граматики дії» в порядку вироблення найбільш загальних норм максимальної доцільності дій, зокрема у вигляді системи загальнотехнічних рекомендацій i застережень стосовно професійної індивідуальної і колективної діяльності (роботі).

Концепція навмисної дії лежить в основі праксиологіï, розробленої австрійським економістом Людвігом фон Мізесом. Під цим унікальним підходом, який визначається як наука про людську діяльність і призначеним для вивчення області соціальних наук, Мізес створює "аксіому дії" твердження, що у кожної людини $є$ більш задовільний стан справ [10]. На думку австрійського вченого “аксіома діï” здатна вивести цілісний фундамент - вартість, масштаб вартості, дефіцит, достаток, прибуток, збиток, невизначеність i причинність, серед усього.

Поява праксеології була заявлена виходом монографії Т. Котарбінського «Трактат про хорошу роботу», в 
передмові до якого Г.Х. Попов писав: «Яке завдання праксеології? ... Знайти загальні закони будь-якої людської діяльності та вивести на цій основі найбільш загальні правила такої діяльності». I далі: «Дуже важливий аспект праксеології - іiі зв'язок із загальними моментами абстрактного процесу праці, сформульованими К. Марксом в «Капіталі». Геніальні думки К. Маркса про загальності праці $з$ повним правом можна назвати відправним пунктом праксеологічного аналізу». [5] Але автор праксеології оцінював іiі завдання більш скромно: «Міркування, що містяться в даній роботі, відносяться до праксеології, або загальної теорії ефективної організації діяльності. Необхідність і можливість розробки такої дисципліни ясні. Адже рецепти ефективної роботи бувають більш-менш загальними. Праксеологія ставить собі за мету дослідження найбільш широких узагальнень технічного характеру: про техніку раціональної діяльності як такої, про вказівки і застереження, важливих для будь-якого дії, ефективність якого необхідно підвищити». Тобто, у Т. Котарбінського мова йде про технічну (в широкому сенсі) діяльності, до якої тільки i застосовні поняття ефективності, «якісної роботи».

Праксеологічний аспект методу складають такі його властивості, як його ефективність, ясність, надійність тощо. На цій основі можливий вибір 3 групи одне порядкових методів найбільш ефективного для того чи іншого суб'єкта, який проводить дослідження [11]. Існує безліч різних методів, які класифікуються за різними підставами: методи якісні i кількісні, змістовні і формальні, історичні та логічні.

Ідеями успішної трансформації стратегії розвитку комунального підприємства є розв'язання таких проблем (Рис.1):

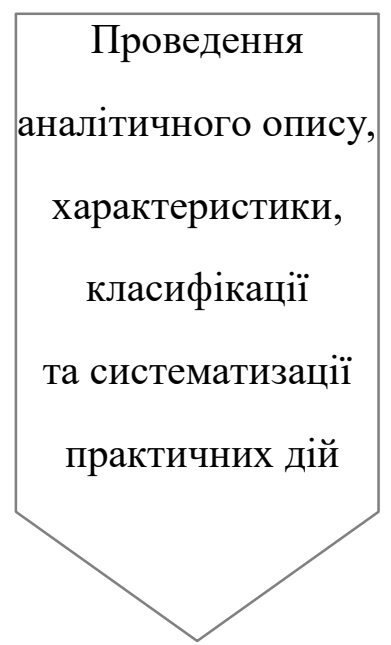

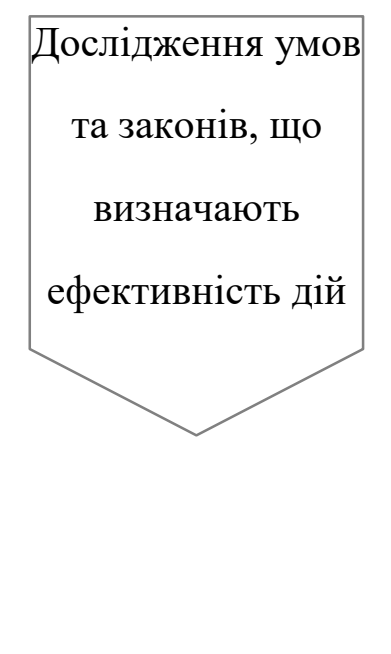

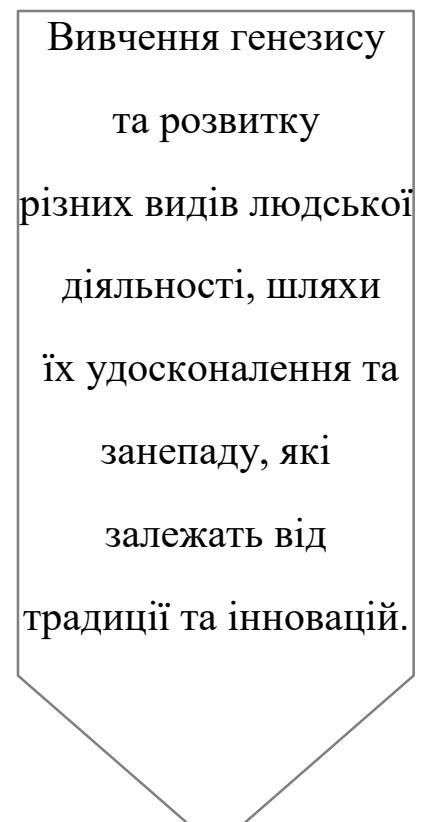

Рис. 1. «Три групи проблем, які вирішує праксеологяя 
Головною метою даної статті $€$ організації в різних методах аналізу і виявлення та вивчення факторів результатів та процесу діяльності підвищення ефективності дій. Існує (Рис.2 певна теоретична основа будь-якої

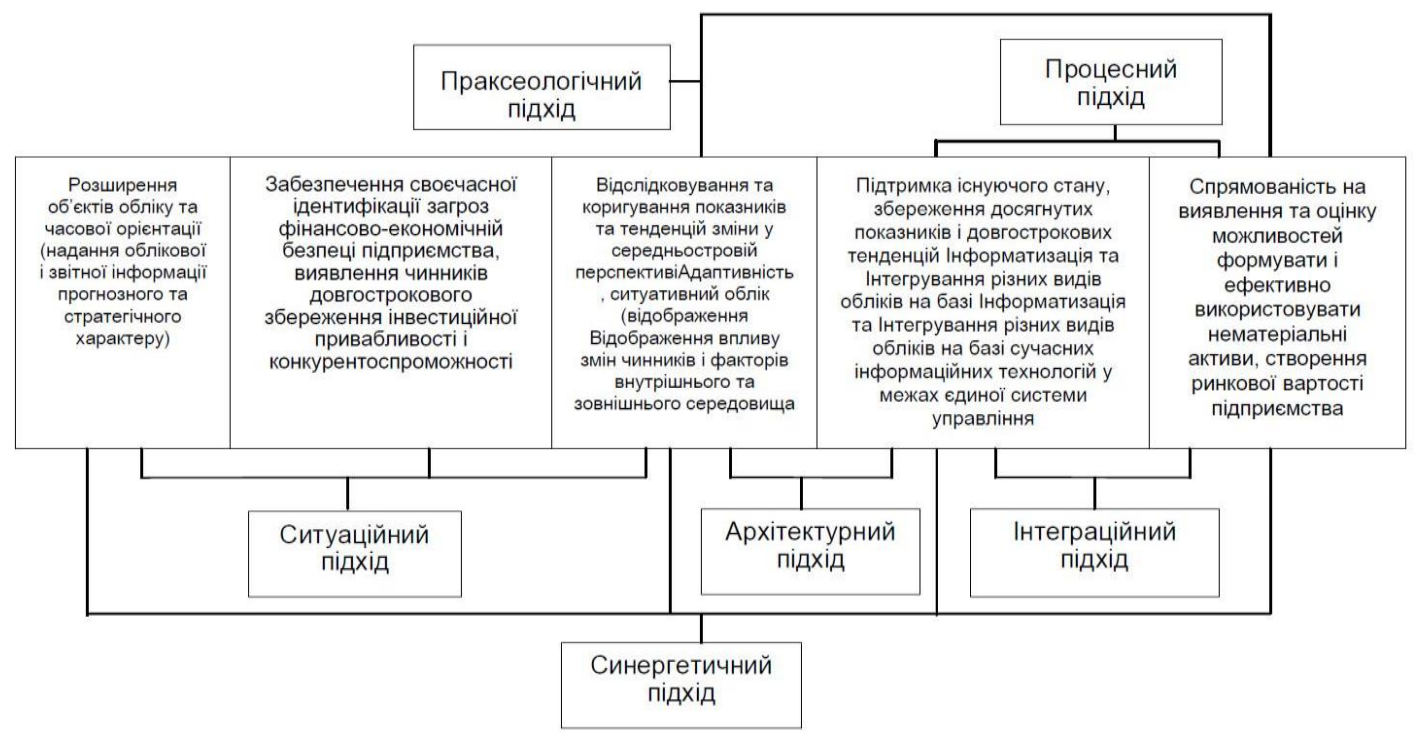

Рис. 2. Групування теоретико-методологічних підходів діяльності підприємства Джерело: [7]

Задля детального вивчення діючих стратегій комунального підприємства Харківводоканал пропонується розгляднути дані щодо дебіторської та кредиторської заборгованостей підприємств житлово-комунального господдарства України за 2017-2018 роки. [3]

Серед регіонів найвищий рівень дебіторської заборгованості спостерігається у Харківській $(2247,5$ млн. грн.), Донецькій (1875,0 млн. грн.), Дніпропетровській (1171,4 млн. грн.) областях та м. Києві (3033,7 млн. грн.). Найнижчий рівень - у Тернопільській (81,8 млн. грн.) та Чернівецькій $(62,8$ млн. грн.) областях. Обсяг дебіторської заборгованості в 2018 році у порівнянні з 2017 роком зменшився в Дніпропетровській (0,2\%), Луганській
(72,6\%), Львівській $(7,6 \%)$ та Одеській $(5,6 \%)$ областях. Що стосується кредиторської заборгованості підприємств житлово-комунального господдарства, то найвищою вона є також у Харківській (3210,9 млн. грн.), Донецькій (3103,3 млн. грн.), Дніпропетровській (1603,2 млн. грн.) областях та м. Києві (3466,9 млн. грн.). Найнижчий iï рівень - у Тернопільській $\quad(86,3$ млн. грн.) та Закарпатській (90,3 млн. грн.) областях. Позитивним є те, що майже в усіх областях, крім Донецької, Запорізької, Івано-Франківської, Чернівецької та Житомирської, спостерігається зменшення кредиторської заборгованості. Отже, аналіз фінансового стану підприємств житловокомунального господарства України 
підтверджує наявність довгострокової системної фінансової кризи, яка охоплює всі напрямки діяльності даних підприємств i загрожує фінансовій безпеці не тільки галузі, але i країни.

Маючи на меті проведення діагностики фінансового стану на підприємствах житлово-комунального господарства пропонується застосування праксеологічного підходу.

Головним етапом подолання труднощів комунального підприємства “Харківводоканал” є розробка ефективної фінансової стратегіï, яка $\epsilon$ головною складовою загальної економічної стратегї функціонування підприємства. Основною ціллю $є$ зміна комунальної форми власності. Саме це буде сприяти росту ефективності роботи підприємства та одночасно підвищенню фінансових надходжень, що $\epsilon$ необхідним для подальшої діяльності і розвитку підприємства.

Необхідно запровадити кращий механізм залучення інвестицій для вирішення проблеми незадовільного фінансування комунального підприємства i скоротити соціальноекономічне напруження, яке було визване постійним зростанням тарифів в той час, коли знижувалася якість та надійність надання послуг [12].

3 метою збільшення експлуатаційних термінів служби обладнання (електродвигунів, механічної та технологічної частини), зменшення аварійності на водогонах за рахунок усунення гідравлічних ударів та ін. проектом передбачається впровадження пристроїв плавного пуску (далі по тексту ППП) високовольтних потужних агрегатів водопровідних насосних станцій 3 можливістю комутації на кожен насосний агрегат, який $\epsilon$ альтернативою застосуванню частотних перетворювачів, впроваджуння яких на даних об'єктах економічно недоцільно [8].

КП «Харківводоканал» протягом останніх десяти років проводить активну роботу 3 енергоресурсозбереження, підвищення енергоефективності виробництва i надання послуг. Це обумовлено тим, що частка паливно-енергетичних ресурсів становить значну частину в собівартості 1 м $^{3}$ продукції (послуг).

На думку авторів, виходячи 3 того, що частка паливно-енергетичних ресурсів становить значну частину в собівартості $1 \mathrm{~m}^{3}$ продукції, цей підрозділ Програми має бути пророблений більш детально.

КП «Харківводоканал» приступає до реалізації інвестиційного проекту «Удосконалення системи мулового господарства каналізаційних очисних споруд міста Харкова». Реконструкція каналізаційного господарства міста буде здійснюватися за рахунок коштів Міжнародного банку реконструкції та розвитку. Вартість проекту - 66 млн дол. США, тривалість - близько трьох років. Для реалізації проекту вже було проведено тендерні торги та визначено переможця. Проект включає повну реконструкцію очисних споруд починаючи від первинного очищення стічних вод до очищення i біологічного складу. Будуть впроваджені методи нітро-денітрифікації, який дозволяє поглиблено чистити стічні води від азоту і фосфору. Також буде побудований комплекс 3 переробки мулу і виробленні з біогазу. 
Підприємство активно працює над реалізацією інвестиційних проектів. У процесі здійснення інвестиційних проектів використовуються інноваційні розробки, що забезпечують екологічну безпеку та підвищують їх економічну ефективність за рахунок зниження споживання енергоресурсів, скорочення експлуатаційних витрат i термінів окупності, зменшення вартості.

Основні напрямки проектів:

- енерго- та ресурсозбереження;

- поліпшення екологічного стану навколишнього природного середовища;

- підвищення надійності роботи систем водопостачання i водовідведення;

- поліпшення якості питної води.

В Програмі в подальшому планується, що буде зафіксовано незначний стабільний рівень зниження витрат на первинні енерго-ресурси (далі по тексту ПЕР). Етап реалізації інвестиційних програм підприємства (2017-2026 рр) потребуватиме вкладення значних коштів для зниження споживання первинних ПЕР.

Виникає необхідність проаналізувати фінансовий стан КП «Харківводоканал». фінансовий стан підприємства характеризується негативними явищами за всіма сферами: прибутковість, ділова активність, ліквідність, фінансова стійкість, що можна пояснити специфічністю діяльності підприємства та його формою власності, яка передбачає високу частку втручання органів місцевої влади в діяльність підприємства.
Впровадження матеріального стимулювання трудових колективів та окремих працівників КП «Харківводоканал» за економію паливноенергетичних ресурсів дозволить підвищити енергетичну ефективність виробництва на КП «Харківводоканал».

На даному комунальному підприємстві «Харківводоканал» широко впроваджуються передові технології в сферах водопостачання та водовідведення. У зв'язку 3 цим підприємству потрібні висококваліфіковані співробітники i керівники підрозділів, які будуть реалізовувати нові стратегічні програми та інвестиційні проекти.

Сьогодні для розвитку виробництва i науки представляється дуже багато можливостей. Це кредити міжнародних банків, гранти для технічного переозброєння підприємства, впровадження енергоефективних технологічних процесів [2].

3 метою підвищення ефективності роботи підприємства, на КП «Харківводоканал» необхідно удосконалити організаційну структуру системи енергоменеджменту, яка повинна діяти у повній відповідності до Національного стандарту ISO 50001:2014.

На даний момент на підприємстві діє довгий ланцюг по збору інформації від відповідальних підрозділів КП «Харківводоканал» до служби енергоменеджменту, це обумовлено багатоступінчастою схемою взаємодії служби енергетичного менеджменту зі структурними підрозділами підприємства.

В рамках своїх завдань щодо 
ефективного управління енергоспоживанням і реалізації заходів Програми енергоефективності, 3 метою виявлення «проблемних місць», пошуку шляхів економії паливно-енергетичних ресурсів та скорочення втрат води, Служба енергоменеджменту проводить системний енергетичний моніторинг споживання енергоресурсів i виявляє відхилення за питомими витратами електроенергії, пропонує рішення по усуненню «проблемних місць».

3 моменту створення в 2011 році Служби енергоменеджменту підприємства, за рахунок системного підходу до питань енергозбереження та енергоефективності, скорочення втрат води, вдалося підвищити ефективність вкладення коштів в енергозберігаючі заходи майже в 2 рази: 3 1,32 грн. (у 2011 р.) до 2,57 грн. (в 2017 р.) на 1 грн. вкладених коштів.

Системний підхід до питань раціонального використання енергоресурсів дозволяє підійти до формування ефективної енергетичної політики, яка $\epsilon$ рушійною силою по впровадженню $\mathrm{i}$ вдосконаленню системи енергоменеджменту підприсмства [9].

Функціонування системи енергетичного менеджменту підприємства за даним стандартом, передбачає створення організаційної структури за типом американських i європейських компаній, до якої можуть входити такі ланки:

-вище керівництво підприємства;

- представник керівництва по системі енергоменеджменту (в американських компаніях - енергодиректор); - структурний підрозділ, що складається 3 енергоменеджерів або осіб (кількість визначається в залежності від величини енергоспоживання підприємства), що виконують їх окремі функції i підкоряється представнику керівництва 3 енергоменеджменту.

Висновки. Дотримучись заданих цілей визначено діючу спратегію розвитку КП «Харківводоканал», застосовуючи саме праксеологічний метод. Отже, згідно аспекту ефективності, можна виділити основні напрями щодо реалізації покращення стратегічного розвитку комунального підприємства «Харківводоканал» [1]: стабілізація фінансово-економічного стану КП «Харківводоканал» шляхом впровадження економічно обгрунтованих тарифів; удосконалення науковотехнічного забезпечення сфери питного водопостачання та водовідведення 3 наближенням їх до стандартів $\mathrm{EC}$; створення обов'язкової системи обліку та контролю втрат води, підвищення інвестиційної привабливості підприємства за рахунок реалізації інвестиційних проектів; утилізація осаду та реконструкції очисних споруд за рахунок реалізації інвестиційного проекту, зазначеного вище, визначення раціональної структури підприємства на підставі підвищення продуктивності праці, оптимізації чисельності робітників, зростання заробітної плати; оновлення парку спеціальних машин та механізмів 3 метою зниження експлуатаційних витрат і скорочення термінів виконання робіт 3 обслуговування мереж водопостачання та водовідведення, завершення реалізації заходів по технологічному та комерційному обліку ресурсів. 
Список використаної літератури

1. Стратегії розвитку міста Харкова до 2020 року: Рішення 10 сессії Харківської міської ради 7 скликання від 21.12.2016 p. URL: http://www.city.kharkov.ua/assets/files/docs/zakon/strategy2411.pdf.

2. Світлична В.Ю. Економічна стратегія розвитку житлово-комунального господарства: формування, специфіка, перспективи. Коммунальное хозяйствогородов: Научн.-техн. сб. Вип. 59. К.: Техніка. 2004. С.78-85.

3. Державна служба статистики в Україні. URL: http://www.ukrstat.gov.ua.

4. Мізик Ю. І. Моделі аналізу фінансового стану житлово-комунальних підприємств регіонів України. URL: http:// khg.kname.edu.ua/index.php/khg/ article/view/1903.

5. Ачкасов А. Е., Косяк А. П. Проблемы и перспективы обеспечения экономической безопасности строительных организаций. БІЗНЕСІНФОРМ. 2012. № 11. URL: http://www.business-inform.net /pdf/2012/11_0/161_166.pdf

6. Онищук Г. І. Економіка житлово-комунального господарства і нові підходи у формуванні цінової і тарифної політики. URL: http://librar.org.ua/sections_load. php?s=business_economic science\&id=2998\& start=14.

7. Боярко I.M. Праксеологічні та ситуаційний підходи у формуванні системи стратегічного обліку. URL: http://fkd.org.ua/article/download/91053/87225/.

8. Директива Свропейського парламенту та ради 2009/28/СС від 23 квітня 2009 року про заохочення до використання енергії, виробленої з відновлюваних джерел та якою вносяться зміни до, а в подальшому скасовуються Директиви 2001/77/ЄС та 2003/30/ЄС (Текст має значення для СЕП). Офіційний вісник Європейського Союзу від 05.06.2009 року - C.16-62. URL: http://saee.gov.ua/documents/dyrektyva_2009_28.pdf.

9. Розвиток відновлюваних джерел енергії в Україні 2017 p. URL: http://abc.in.ua/wp-content/uploads/2017/03/Rozvitok-VDE-v-Ukrai-ni.pdf.

10. Енергетична стратегія України на період до 2030 року. URL: http://zakon.rada.gov.ua/signal/kr06145a.doc.

11. Альтернативна енергетика України: сонце, вітер і вода. URL: https://news.fi nance.ua/ua/ news/-/353701/alternatyvna-energetyka-ukrayiny-sontse-viter-i-voda.

12. Структури тарифів на централізоване водопостачання та водовідведення. URL: http://www.nerc.gov.ua/?id=15180. 